\title{
Glaciological Studies on Mount Wrangell, Alaska, 1961
}

\author{
CARL S. BENSON ${ }^{1}$
}

\begin{abstract}
Snow pit studies (3 to $4 \mathrm{~m}$. deep, extended by core drilling to $10 \mathrm{~m}$.) involving temperature, density, hardness and stratigraphy profiles were made at 5 locations in the caldera and an adjacent snow-filled crater. The facies parameters calculated for the summit area of Mount Wrangell $(4,000$ to $4,300 \mathrm{~m}$. at $62^{\circ} \mathrm{N}$.) compare well with the same parameters near the dry-snow line on the Greenland Ice Sheet. The mean annual temperature, based on measurements $10 \mathrm{~m}$. below the snow surface in the centres of the caldera and inactive craters, is $-20^{\circ} \mathrm{C}$. Effects of volcanic heating were observed near the edge of the caldera. Accumulation was abnormally high during the 1961 summer. It varies markedly with topography and the mean annual value exceeds $100 \mathrm{~cm}$. water equivalent in smooth central areas of the caldera and adjacent craters. Surface velocity was measured by triangulation on a network of poles from control points on the caldera rim; the average value in the caldera was about $5 \mathrm{~cm}$. day ${ }^{-1}$ or about $20 \mathrm{~m}$. yr. ${ }^{-1}$.
\end{abstract}

RÉSUMÉ. Études glaciologiques sur le mont Wrangell, Alaska, 1961. En cinq points de la caldéra et du cratère voisin rempli de neige, on a mené des études sur la neige, au moyen de trous profonds de 3 à $4 \mathrm{~m}$ prolongés par des carottes jusqu'à 10 m.: les études ont porté sur la température, la densité, la dureté et les profils stratigraphiques de la neige. Les paramètres de faciès calculés pour le sommet du mont Wrangell $\left(4,000\right.$ à $4,300 \mathrm{~m}$., $62^{\circ} \mathrm{N}$.) se comparent très bien aux mêmes paramètres calculés près de la limite de la neige sèche sur la calotte groenlandaise. A $10 \mathrm{~m}$. sous la surface au centre de la caldéra et au centre des cratères inactifs, la température moyenne annuelle est de $-20^{\circ} \mathrm{C}$. Près du bord de la caldéra, on a observé des effets de réchauffement volcanique. Au cours de l'été de 1961, l'accumulation nivale a été anormalement élevée. Elle varie de façon marquée selon le relief et sa valeur annuelle moyenne dépasse $100 \mathrm{~cm}$ en équivalent d'eau dans les parties centrales de la caldéra et des cratères. On a mesuré le mouvement de la surface par triangulation d'un réseau de pieux, à partir de points de contrôle situés à la bordure de la caldéra; dans la caldéra, la valeur moyenne était de $5 \mathrm{~cm} /$ jour $^{-1}$, soit environ $20 \mathrm{~m} / \mathrm{an}^{-1}$.

РЕЗЮМЕ. Глячиологические исследования на вулкане Вранеель (Аляска, 1961 г.). Исследования выработок в снегу глубиной в 3-4 м с последующим колонковым бурением на глубину до 10 м были проведены на пяти площадках в кальдере и в примыкающем к ней кратере. Исследования включали измерения температуры, плотности и твердости снега, а также изучение стратиграфического профиля. Параметры фаций, рассчитанные для вершины вулкана на высоте в $4000-4300 \mathrm{~m}\left(62^{\circ} \mathrm{N}\right)$, весьма сходны со значениями, полученными вблизи границы сухого снега на Гренландском ледяном покрове. Средняя годовая температура, измереннал на глубине 10 м от поверхности снега в центральных частях кальдеры и бездействующих гратеров, равнялась $-20^{\circ} \mathrm{C}$. У краев кальдеры было отмечено влияние вулканического тепла. Накопление снега летом 1961 г. было необычайно высоким. Оно заметно зависит от ландшафта и его среднегодовое значение превышает 100 см водного әквивалента в пологих центральных частях кальдеры и примыкающих кратеров. Поверхностные скорости были измерены по сети реек методом триангуляции с опорных точек, расположенных на краю кальдеры. Средняя скорость в кальдере равнялась $\sim 5$ см/день, т.е. $\sim 20$ М/ГОд.

${ }^{1}$ Geophysical Institute, University of Alaska, College, Alaska. 


\section{INTRODUCTION}

The Wrangell Mountains $\left(61^{\circ} 30^{\prime} \mathrm{N}\right.$. to $62^{\circ} 30^{\prime} \mathrm{N}$. and $142^{\circ}$ to $145^{\circ} \mathrm{W}$.) lie north of the Chugach Range and trend Northwest from the St. Elias Range. They are bracketed on the north and northwest by the Copper River and on the south by the Chitina River. The eastern boundary is probably best placed at Chitistone Pass and the White River; however, by way of Mts. Bona, Bear, Craig, Wood, Steele, etc. one could consider the Wrangell Mountains to be part of the St. Elias Range.

The continuous snow and ice cover in the Wrangell Mountains covers 5,080 $\mathrm{km} .^{2}$. Indeed the top of Mount Wrangell itself is an ice cap with ice flowing outward in all directions (Fig. 1). As stated by Sharp (1956, p. 101): “. . . Wrangell Mountains are mantled by the most compact glacier systems in Alaska. This is partly due to elevations locally exceeding 16,000 feet (approximately $4,900 \mathrm{~m}$.), to a topography that favours an extensive cover of upland ice, and to somewhat lower coastal mountains to the south and southwest."

The Wrangell Mountains were selected for a reconnaissance glaciological study in 1961 because they appeared to have the greatest accessible span of glacier

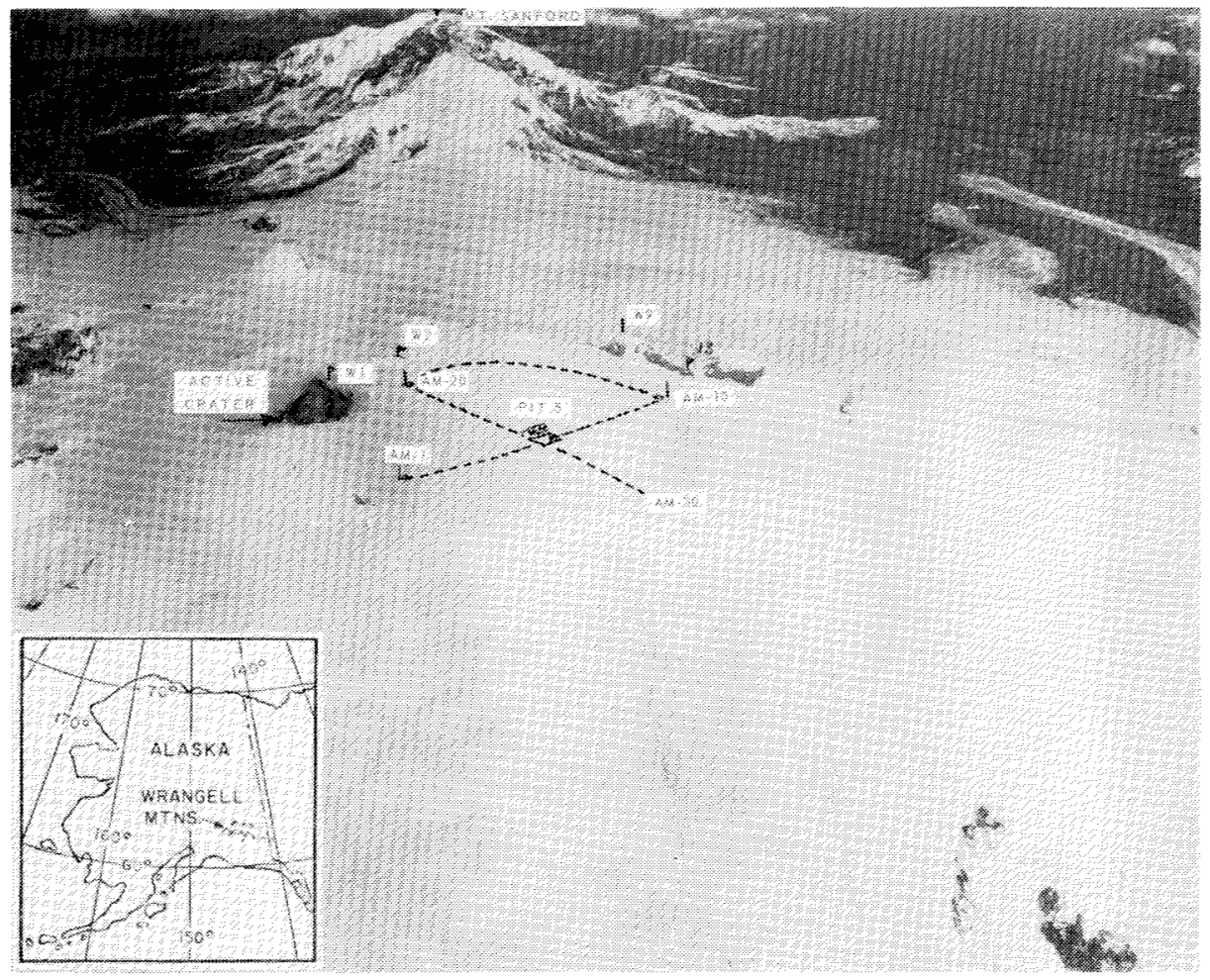

FIG. 1. Northward view of research area in and around the caldera on top of Mt. Wrangell, altitude $4,200 \mathrm{~m}$., standard atmosphere pressure $600 \mathrm{mb}$. The coordinates $62^{\circ} \mathrm{N}$., $144^{\circ} \mathrm{W}$. cross near point W3. The 1961 camp was located on the rim of the North Crater at point W2. Triangulation points are W1, W2, W3; Accumulation-movement markers, labelled AM1, AM2, etc., were located along the dashed lines. 


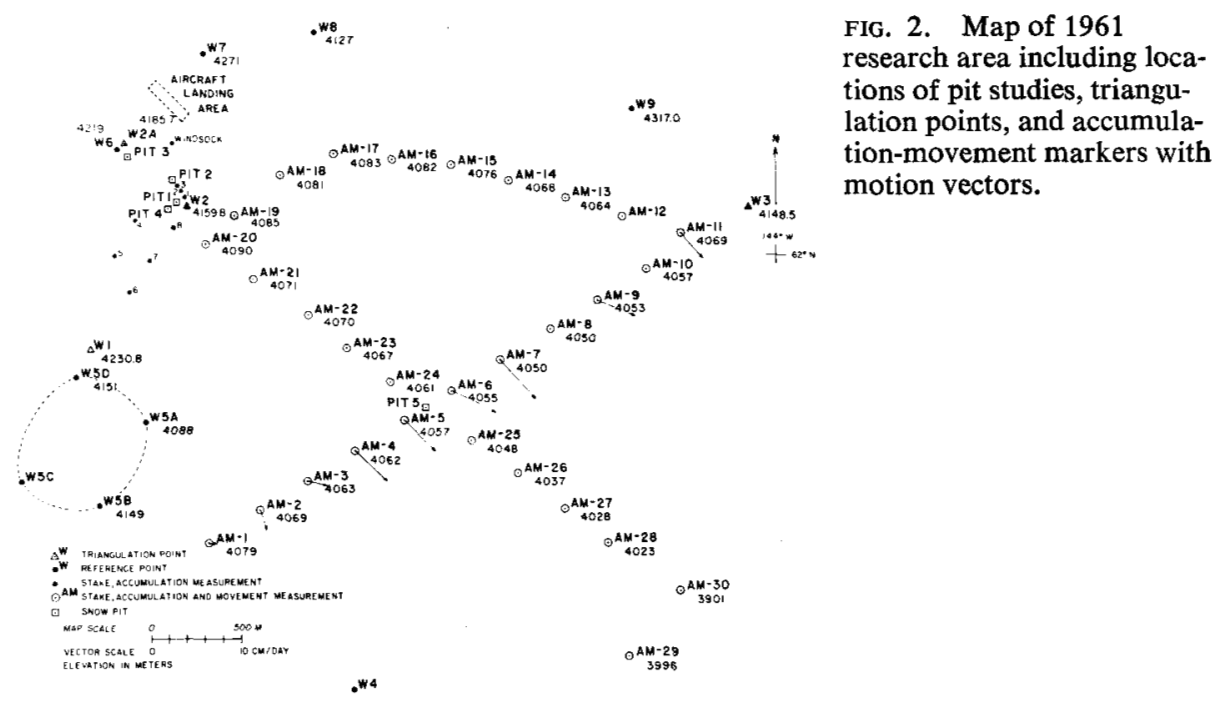

facies in Alaska (Benson 1962a, 1963). It was expected that all four glacier facies would be encountered. Glaciers on Mount McKinley undoubtedly have a greater altitudinal span of the dry-snow facies - as well as a greater total range of environment. However, that mountain was considered to be too complex from the logistic point of view to be chosen for the study. On the other hand, Mount Wrangell is only $74 \mathrm{~km}$. (46 miles) from the Gulkana Air Strip and was the site of a cosmic ray research program, carried out jointly by New York University and the University of Alaska during 1953 and 1954 (Beiser 1953). Two Jamesway huts were erected near point W2 (Figs. 1 and 2) as part of the 1953-54 program. The 1961 campsite was located near the abandoned Jamesway huts in the hope that they would be of some use in our glaciological program. Furthermore, the overall glacier regimen in the Wrangell Mountains is an important link between studies in the Alaska Range (Sellmann 1962; Rutter 1961; Mayo 1963) and in the St. Elias Range (Wood 1963).

One of the main purposes of the research on Mount Wrangell was to conduct detailed physical measurements in the upper $10 \mathrm{~m}$. of the snow cover and to analyze them in comparison with similar measurements made on the Greenland and Antarctic ice sheets. The facies classification of glaciers (Benson 1962a) was used to construct a "hypothetical North Polar Ice Sheet" which served as a frame of reference. Briefly, this concept is based on the assumption that the Greenland ice sheet behaves as if it were part of a much larger ice sheet, which is symmetrical about the North Pole. In the Arctic, the complex distribution of water alternating with irregular land areas interrupt our hypothetical North Polar Ice Sheet to the extent that only tiny "fragments" of it remain. A good picture of the fragments is formed by the location maps of Arctic glaciers in the Western and Eastern hemispheres presented by Sharp (1956, Figs. 1, 2). Among the larger fragments are the $8,220 \mathrm{~km}{ }^{2}$ Vatnajökull Ice Cap in Iceland and the $5,058 \mathrm{~km} .{ }^{2}$ ice cap of the Wrangell Mountains.

The largest fragment, of course, is the Greenland ice sheet which is about $1 / 8$ 


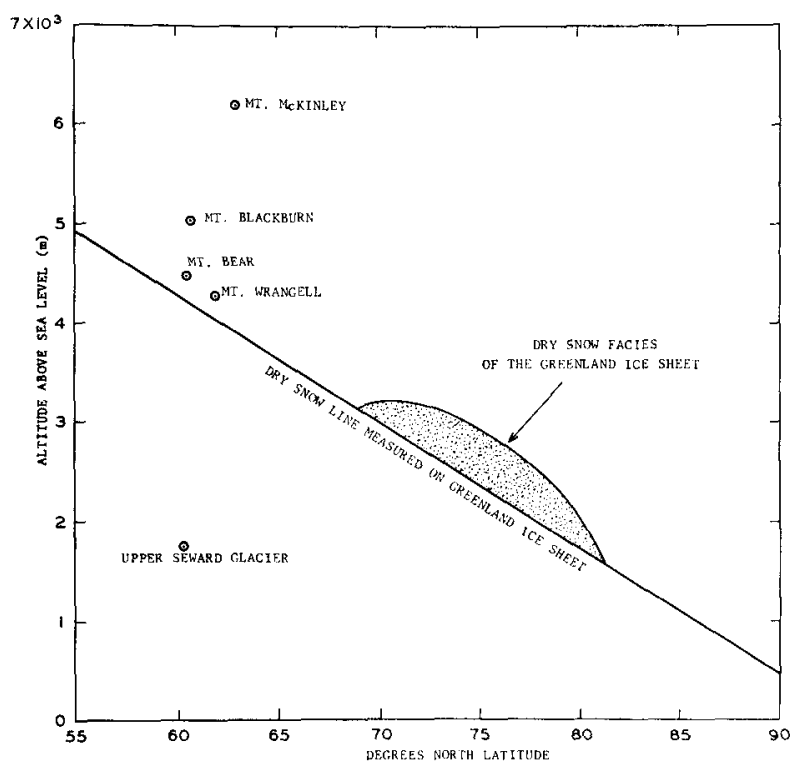

FIG. 3. Latitude-altitude relationship of the dry-snow line. The measured location of the dry-snow line on the Greenland ice sheet has been extrapolated to compare it with the altitudes and latitudes of selected Alaskan mountains. Qualifications resulting from obvious climatic differences are discussed in the text.

the area of Antarctic ice sheet and has its center located about $18^{\circ}$ from the geographic pole. However, in spite of this, it appears to control its climate, at least its temperature, in a manner similar to that actually observed on our only large ice sheet with polar symmetry. This conjecture is supported by extrapolating the latitude gradient of temperature determined on the Greenland ice sheet (Benson 1962a; Mock and Weeks 1966) to $90^{\circ} \mathrm{N}$., and replacing the altitude at the North Pole (sea level) by the altitude observed at the South Pole $(2,800 \mathrm{~m}$.). The calculated mean annual temperature at this imaginary North Pole is $-46.5^{\circ} \mathrm{C}$. (Benson 1962b). It compares well with the mean annual temperatures of $-50^{\circ} \mathrm{C}$. measured $2.5 \mathrm{~m}$. above the snow surface, and $-50.9^{\circ} \mathrm{C}$. measured $12 \mathrm{~m}$. below the snow surface, at the real South Pole (Giovinetto 1960).

The dry snow line may be expressed in terms of altitude and latitude because it is independent of accumulation (Benson 1962a, p. 74). On the Greenland ice sheet, it descends toward the north at the rate of $1.15 \mathrm{~m} . / \mathrm{km} .(127 \mathrm{~m}$. per degree latitude) being $3,000 \mathrm{~m}$. above sea level at $70^{\circ} \mathrm{N}$. If the dry-snow line were to show the same altitude-latitude relationship in the rest of the Arctic, it would range from $4,250 \mathrm{~m}$. at $60^{\circ} \mathrm{N}$. to $500 \mathrm{~m}$. at $90^{\circ} \mathrm{N}$. (Fig. 3). Thus, it appears likely that the dry-snow line may be present in the Wrangell Mountains and certainly on Mount McKinley. Since Alaskan glaciers are mountain glaciers, they will show a pronounced effect of north and south slope exposure on the location of facies boundary lines. This effect was not encountered in the Greenland research because of the nearly horizontal surface of the ice sheet. Also, the discontinuous, complex distribution of ice masses in the western Arctic should lead us to expect the dry-snow line to be translated to higher altitudes than observed in Greenland. Conversely, the more continuous, symmetrical situation in Antarctica may cause the line to be translated to lower altitudes. The use of this hypothetical North 
Polar Ice Sheet in comparing various points in Alaska and Arctic Canada with Greenland and Antarctica is treated in more detail by Benson (1967).

\section{SCOPE OF THE FIELD WORK}

During the 1961 summer a research area was selected and studies were begun in the caldera and an adjacent crater (the North Crater) at 4,000 to $4,300 \mathrm{~m}$. altitude on top of Mount Wrangell (Benson, 1963). The research effort had two main objectives: one was a series of snow-pit studies which were made at 5 locations, 4 of them in the North Crater (Fig. 4) and the 5th in the centre of the caldera itself (Figs. 1 and 2). Temperature, density, hardness, and snow stratigraphy were measured in each pit with the aim of determining physical characteristics of the snow cover, and the rates of accumulation. The data from these pits are plotted in Figs. 5 and 6, and their locations are shown in Fig. 2. The methods of obtaining information from pit studies, and the standard format for plotting the data are discussed elsewhere (Benson 1962a).

The second objective involved a network of 30 accumulation and movement markers (bamboo poles, identified as AM-1 to AM-30 in Fig. 2) which was established in the caldera. To determine the rate of flow of ice in the caldera, as

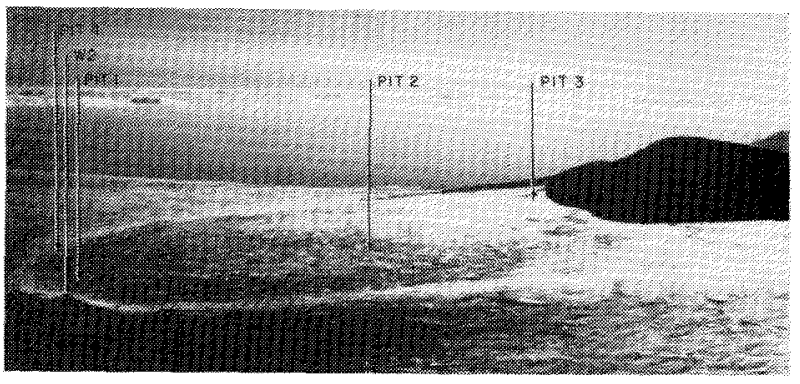

FIG. 4. Aerial view of the North Crater with locations indicated for pits and the shelter near survey point W2.

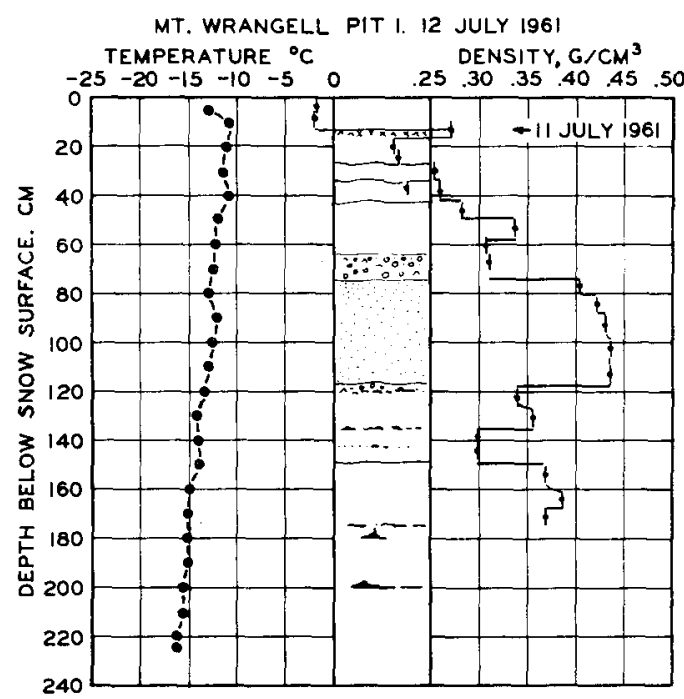

FIG. 5. Stratigraphic data from Pit 1, Wed. 12 July 1961 . No ram hardness profile was measured because the Rammsonde penetrometer had not arrived on the mountain by the time this study was made. 


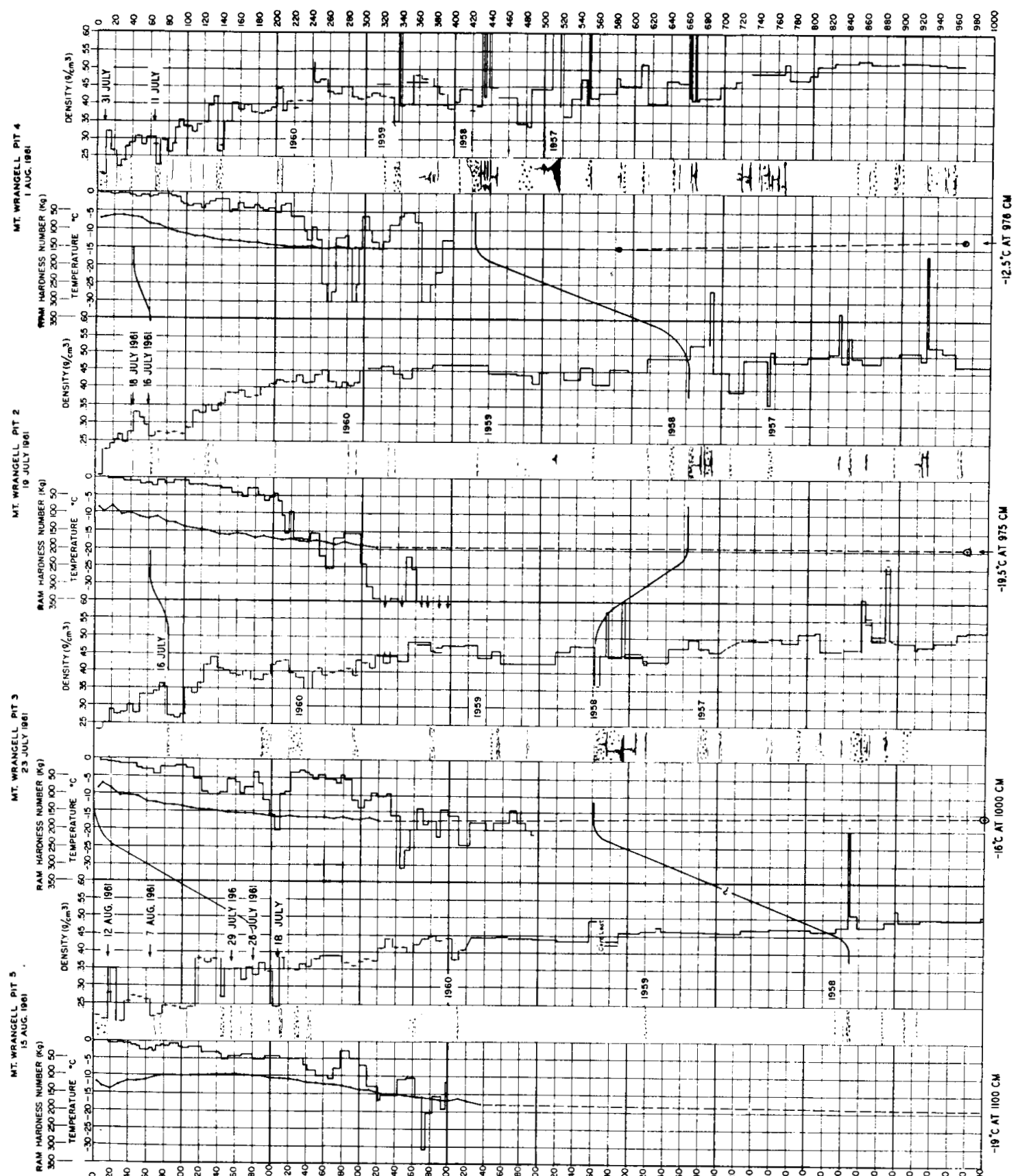

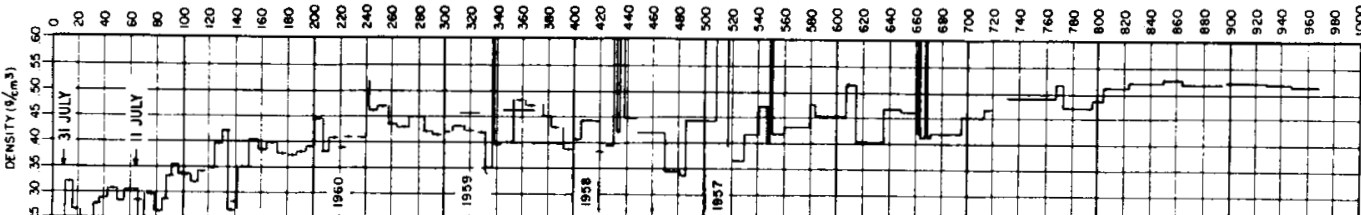
西 3 -4) ic 
seen by movement on the snow surface, these poles were surveyed several times from 3 control points (W1, W2, and W3 of Fig. 2) around the edge of the caldera. To determine accumulation the snow surface was marked, as in Greenland, by laying a piece of plywood at each pole. The accumulation was measured by probing, with a graduated steel rod, to the board at each stake after each snowstorm.

It was not possible to lay out the entire AM network in one day; AM-1 to AM-19 were set on 26 July, AM-20 to -24 on 12 August, and AM-25 to -30 on 14 August. Almost $3 \mathrm{~m}$. of snow accumulated between 25 July and 26 August in the caldera and nearly buried the network of marker poles which had to be completely reset on 25 and 26 August. Stakes 1 to 8, and the one labelled "windsock" were not part of the AM network. The board at Pit 2 may be considered as the replacement for stake 3 which was lost before the field season was over (Fig. 2).

\section{STRATIGRAPHY}

\section{Physical Features of the Snow Cover}

The data from Pit 1 are plotted in Fig. 5. The data from Pits 2, 3, and 4 of the North Crater and Pit 5 of the caldera are plotter together in Fig. 6.

The locations of the four pits in the North Crater were determined, as the work progressed, in such a way as to trace variable thicknesses of the snow strata. Significant variation occurs in thickness: the layers are thickest in the centre of the crater and thin out toward the edges. The limiting case is at the south edge of the North Crater (near W2, Figs. 1, 2, and 4) where bare ground is exposed because of the combined effects of wind action and volcanic heat.

Pit 1 was located near the tent camp in the North Crater, approximately $50 \mathrm{~m}$. from W2 (Fig. 4). It provided information on the temperature, density, and general physical appearance of the snow, which was found to contain traces of volcanic ash and sand in some layers.

Pit 2 was located near the centre of the North Crater where snow layers were thickest. Pits 3 and 4 were located near the northwest and southwest edges respectively, of the North Crater (Fig. 4). The snow layers were thinnest in Pit 4.

Pit 5 was located near the centre of the caldera (Figs. 1 and 2). No volcanic ash or dust was observed in the 11 metres of strata which were examined in Pit 5; in this sense it differed markedly from the pits dug in the North Crater. The storm winds during July and August 1961 were from $190^{\circ}$ to $210^{\circ} \mathrm{T}$. They blew volcanic debris northward onto the snow in the North Crater from the Active Crater and from local patches of bare ground on the windward (south) rim of the North Crater. None of this type of debris blew out onto the snow cover in the centre of the caldera, because there are only a few rock outcrops south of the caldera, and these consist mostly of well indurated material often covered with rime ice, which provide little sedimentary source material for the winds to pick up. As a result of this, the snow stratum observed in pits dug in the caldera is much cleaner than that observed in pits dug in the North Crater.

The 1961 summer was very stormy and pit studies were made during breaks between the storms. This was a nuisance and many pit studies, including analysis of the cores, took several days to complete when the work was slowed by problems 


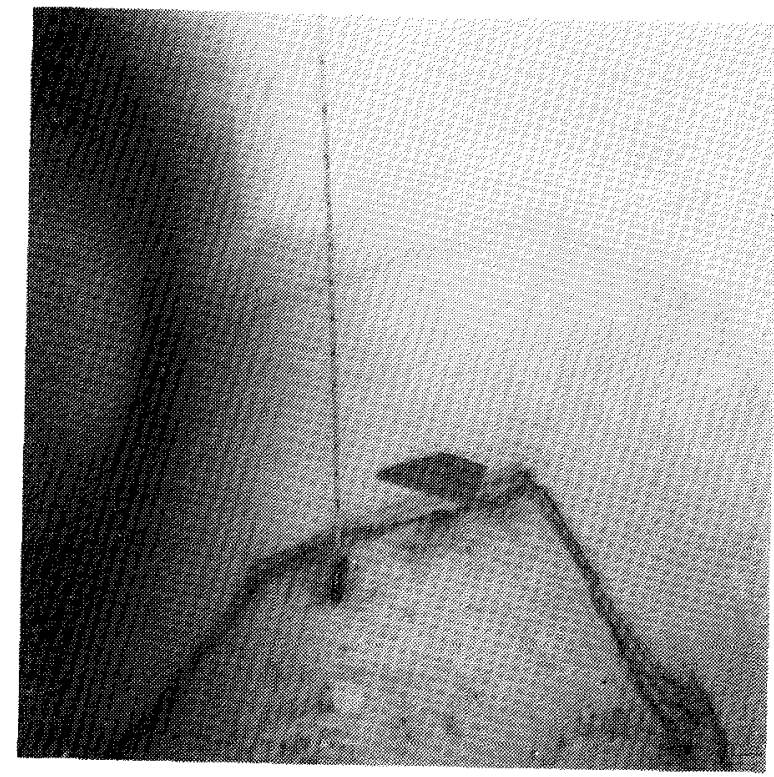

FIG. 7. Dirty melt layer of 1958 exposed at $420 \mathrm{~cm}$. depth in Pit 4. This layer contains a large amount of volcanic debris amidst iced firn, and is underlain by ice lenses and glands (see Figs. 6 and 8).

created by the weather. However, the fact that accumulation was added intermittently during the field season provided several well dated, identifiable horizons in the snow strata.

The dated horizons which were identified in the pit studies formed on: 11, 16, 18, 23, 30 and 31 July 1961, and on 7 and 12 August 1961. The snow surface on 25 and 26 August 1961 was the final dated horizon of the 1961 field season, and accumulation measurements were made at all pit sites and stakes on one of these two days. The locations of some dated levels are shown in Fig. 6.

In addition to the dated horizons mentioned above there was one excellent, but undated, layer which contained a large amount of volcanic debris imbedded in iced firn. It was underlain by abundant ice glands and lenses. Pit 1 was not deep enough to encounter this horizon, and it was observed only in the cores drilled from below Pits 2 and 3, so Pit 4 was located close to the south rim in hopes of exposing it on the pit wall itself. This effort proved successful, and the dirty layer was found $420 \mathrm{~cm}$. below the snow surface (Figs. 7 and 8). It had a great deal of melt evidence associated with it and could be unquestionably correlated with the layer at $665 \mathrm{~cm}$. in Pit 2, and at $562 \mathrm{~cm}$. in Pit 3; it is tentatively correlated with the melt evidence at 847 to $851 \mathrm{~cm}$. in Pit 5. This layer is identified in Fig. 6.

\section{Accumulation}

The accumulation on top of Mount Wrangell during the 1961 summer came in large increments. The values can be put in perspective by two examples: (1) Consider stake AM-5 near the centre of the caldera. Four storms during the 30 days between 26 July and 26 August deposited $263 \mathrm{~cm}$. of snow which, according to the integrated depth-density profile at nearby Pit 5 , amounted to $81.6 \mathrm{~cm}$. of water equivalent. This is ten times more than the $8.15 \mathrm{~cm}$. of precipitation 


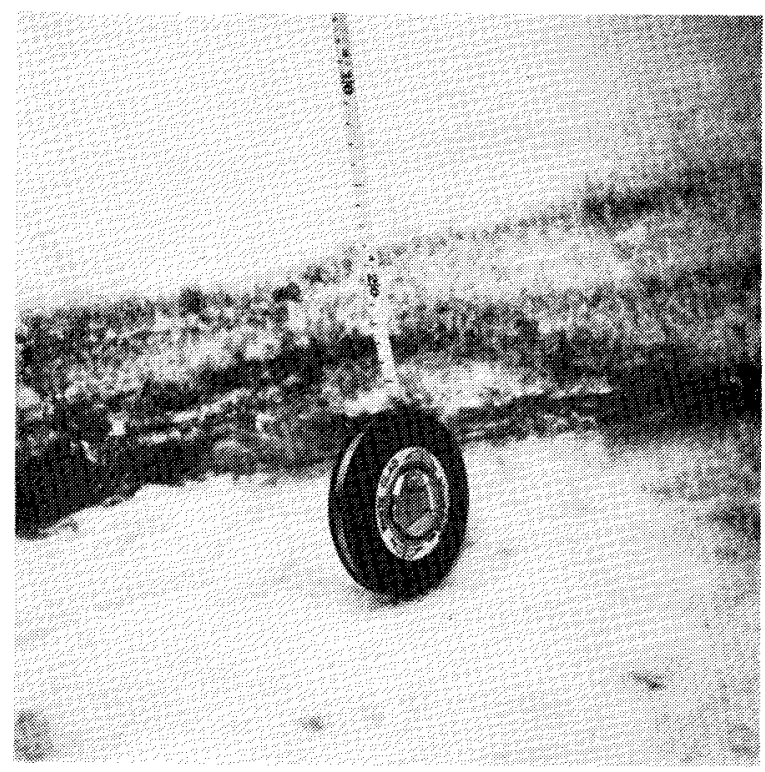

FIG. 8. Close-up view of the dirty melt layer shown in Fig. 7. This horizon is identified as belonging in the 1958 summer (see Fig. 6).

FIG. 9. Test wall of Pit 2 showing the snow which was deposited between 11 and 19 July 1961. This snow contained the equivalent of $34 \mathrm{~cm}$. water which is equal to the average annual accumulation for the Greenland ice sheet.

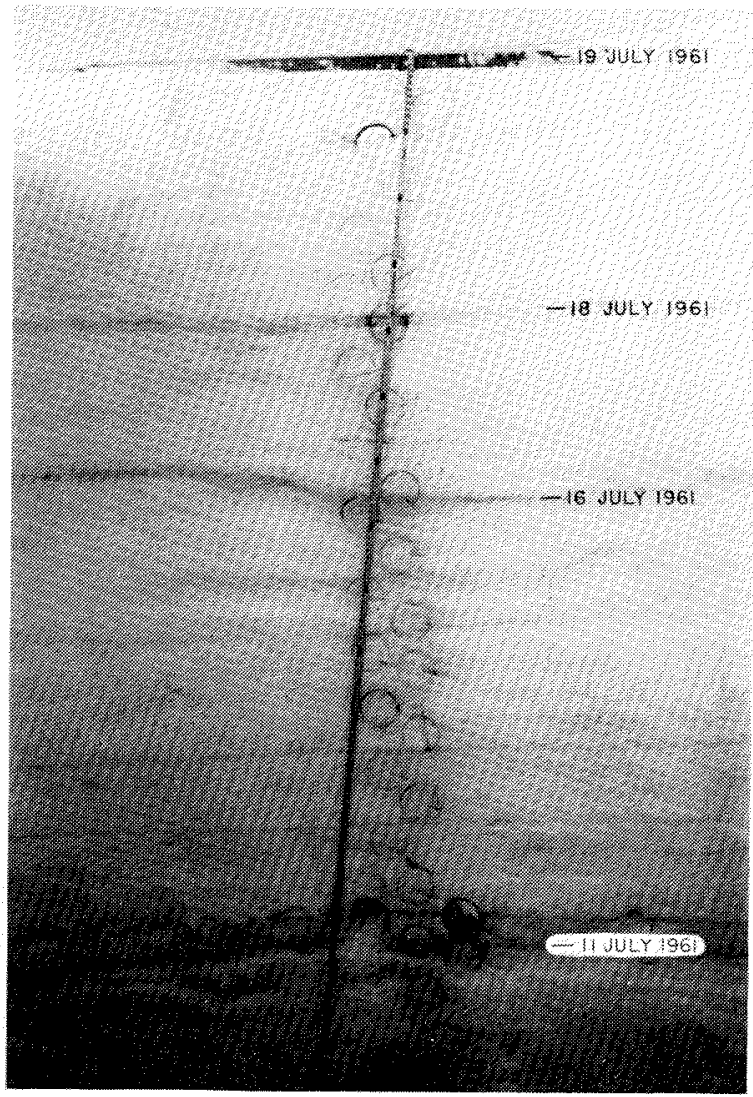


which was recorded during the same time interval at the Gulkana FAA Station in the adjacent lowlands. This Station is located $74 \mathrm{~km}$. from the summit of Mount Wrangell at an altitude of $480 \mathrm{~m}$. above sea level. (2) At Pit 2, the snow of three storms during the 8 days between 11 and 19 July (see Figs. 6 and 9) contained $34 \mathrm{~cm}$. of water equivalent - this is equal to the average annual accumulation on the Greenland Ice Sheet (Benson 1962a, p. 89).

\section{Accumulation}

Perhaps the best way to discuss the accumulation on Mount Wrangell is to begin with the dozen storms which were experienced during the field season and are listed in Table 1. There was no measurement of accumulation on top of Mount Wrangell before 11 July even though 3 storms are listed before the 11th. This is because we were completely involved in getting a camp established on the mountain during the time between 24 June and $10 \mathrm{July}$. The first member of the field party arrived at the summit on 8 July.

The accumulation measured on the snow boards during the storms listed in Table 1 is summarized in Table 2.

The reading at AM-6 on 16 August (see Table 2) is surprising because there was no evidence of wind erosion between 14 and 16 August. However, the total accumulation measured at this stake on 25 August is also anomalously low. This anomaly was neglected in drawing the contours on Fig. 10.

TABLE 1. Storms experienced during the 1961 field season.

\begin{tabular}{|c|c|c|}
\hline Storm & Date $(196 I)$ & Comments \\
\hline A & 1-7 July & $\begin{array}{l}\text { No accurate measurement of accumulation was made but on } 8 \text { July there was more } \\
\text { than } 50 \mathrm{~cm} \text { of snow on equipment which had been cached on } 27 \text { June. This storm } \\
\text { delayed the flying of people to the summit area. }\end{array}$ \\
\hline B & 8 July & Wind from south with new snow lasted nearly all day. \\
\hline $\mathbf{C}$ & 10-12 July & $\begin{array}{l}\text { Wind from south with new snow, the stratigraphic record obtained in Pit } 1 \text { during } \\
\text { this storm gave a base for subsequent accumulation determinations. }\end{array}$ \\
\hline $\mathbf{D}$ & 13-14 July & Wind from south with intermittent snowfall. \\
\hline $\mathbf{E}$ & 17-19 July & $\begin{array}{l}\text { Winds very strong from south with snowfall, sleet and rime ice. The first hexagonal } \\
\text { tent was torn apart and buried by the storm on } 17 \text { July. Abundant rime ice formed } \\
\text { on } 18 \text { July. Stakes and surface marker boards set on } 16 \text { July began recording accu- } \\
\text { mulation with this storm (see Table } 2 \text { ). }\end{array}$ \\
\hline $\mathbf{F}$ & 21 July & $\begin{array}{l}\text { Winds from south with solid cloud cover on mountain but little new snow accu- } \\
\text { mulation. }\end{array}$ \\
\hline G & $27-28$ July & Winds strong from south with about $30 \mathrm{~cm}$ of new snow accumulated. \\
\hline $\mathbf{H}$ & 30-31 July & $\begin{array}{l}\text { Winds strong from south, snow turned to freezing rain on } 30 \mathrm{July} \text {. Extremely heavy } \\
\text { rime ice formed on } 30 \text { July and continued with less intensity on } 31 \text { July. }\end{array}$ \\
\hline I & 2-5 August & $\begin{array}{l}\text { Strong winds from south were steady for four days and brought about } 130 \mathrm{~cm} \text { of new } \\
\text { snow (Table 2). The second hexagonal tent was destroyed at about } 04: 00 \text { on } 5 \text { August. } \\
\text { The pole bent and broke into three pieces, the fabric was torn to shreds, and the ruins } \\
\text { were buried nearly } 2 \mathrm{~m} \text { by drifts. }\end{array}$ \\
\hline $\mathbf{J}$ & 8-10 August & $\begin{array}{l}\text { Winds from the south blew steadily for more than } 70 \text { hours. They were very strong } \\
\text { with gusts estimated to be over } 100 \text { knots. The third tent blew apart at } 18: 30 \text { on } 9 \\
\text { August with loss of some equipment and bedding as well as complete loss of the tent. }\end{array}$ \\
\hline $\mathbf{K}$ & 13-14 August & $\begin{array}{l}\text { Strong winds from south with snowfall most of } 13 \text { August, followed by intermittent } \\
\text { snowfall and variable winds on } 14 \text { August. }\end{array}$ \\
\hline L & 17-24 August & $\begin{array}{l}\text { Winds began from west on } 17 \text { August with clear sky, changed to strong south wind } \\
\text { with overcast in the afternoon. Snow began on } 18 \text { August and changed to freezing } \\
\text { rain on } 19 \text { August. Abundant rime ice formed on } 19 \text { August. Strong winds biew from } \\
\text { the south with new snow and blowing snow from the afternoon of } 17 \text { August until } \\
\text { late on } 24 \text { August. Rime ice formation was especially severe on night of } 22-23 \text { August } \\
\text { (Fig. 15). Skies cleared on } 24 \text { August but wind remained strong until early } 25 \text { August. } \\
\text { About one meter of snow accumulated during this eight day period of relentless } \\
\text { wind (see Table 2). }\end{array}$ \\
\hline
\end{tabular}


TABLE 2. Snow Depth Measurements 1961.

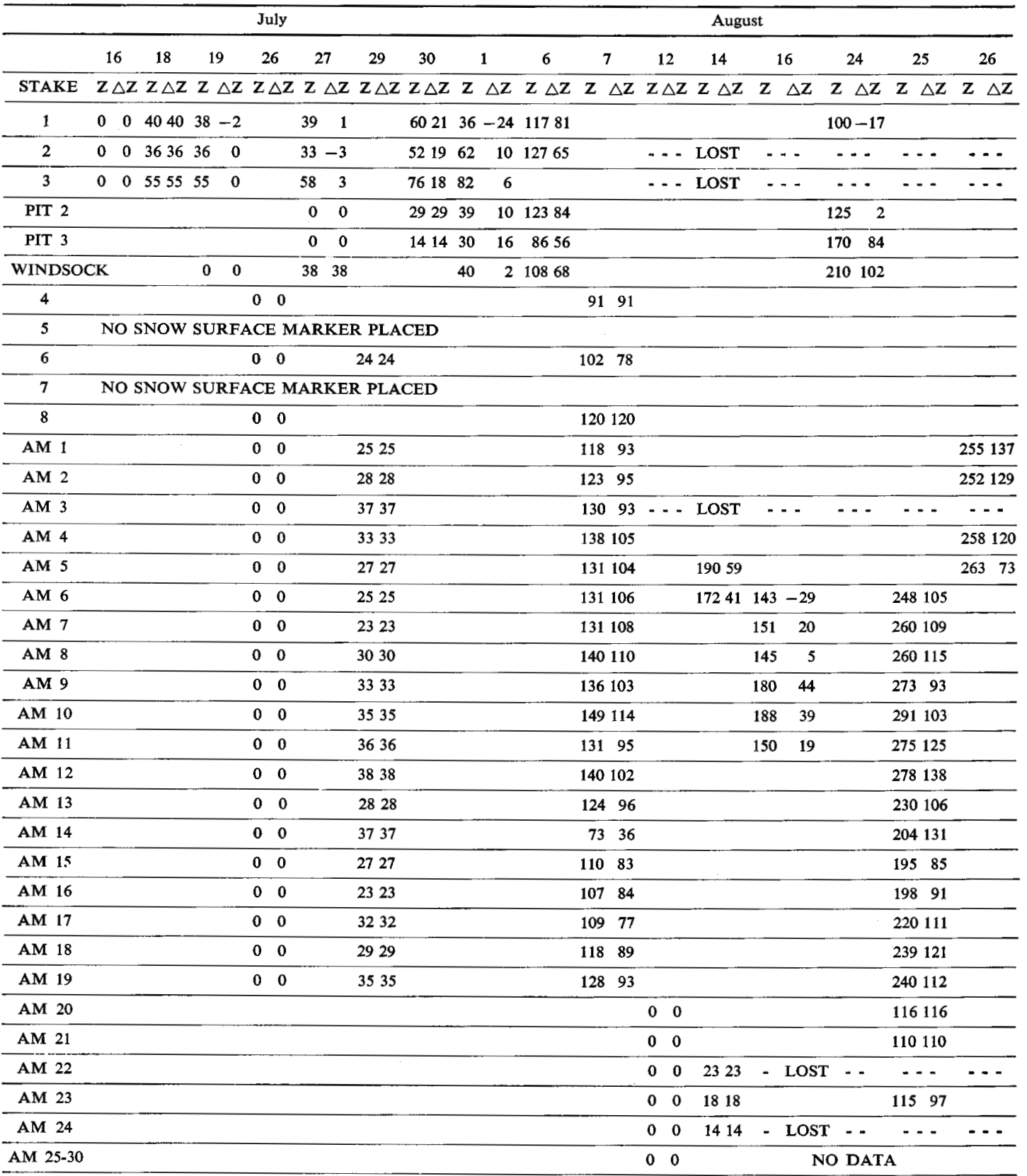

Z: DEPTH TO SNOW BOARD CM.

$\triangle Z$ : INCREASE IN DEPTH TO SNOW BOARD SINCE PREVIOUS MEASUREMENT. 


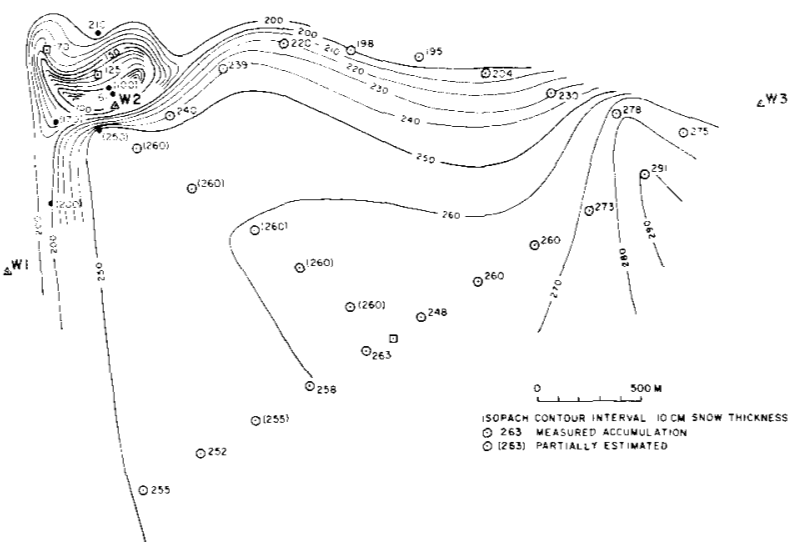

FIG. 10. Isopachs of snow thickness deposited between 26 July and 26 August 1961.

The last entries (24 to 26 August) in Table 2 represent the snow accumulated during storms $G$ through $L$ at all stakes, except those numbered: 1, 2, 3, 4, 6, 8, AM-3, and AM-20 through AM-24. However, values of the accumulation from storms $\mathrm{G}$ through $\mathrm{L}$ can be obtained from these stakes. The accumulation record at stake number 1 indicates $61 \mathrm{~cm}$. of snow accumulation from storms $\mathrm{G}$ through $\mathrm{L}$ when the amount of snow present on 27 July is subtracted from the last entry. The accumulation from storms $G$ through $L$ is not so easily obtained from the other stakes because they had incomplete records. However, the record from individual storms at these stakes can be compared with the records of adjacent stakes to select comparable points to use in obtaining estimates for the total " $\mathrm{G}$ through L" accumulation. The stakes in question are located as follows:

Numbers 2 and 3 in the North Crater,

Numbers 4, 6 and 8 southwest of the North Crater, and

AM-3, 20, 21, 22, 23, and 24 in the caldera.

The estimated values are listed in Table 3 and appear in parentheses in Fig. 10.

TABLE 3. Estimated accumulation from storms $G$ through $L$ at eleven stakes with incomplete records.

\begin{tabular}{rcc}
\hline Stake & $\begin{array}{c}\text { Accumulation (cm. snow) } \\
\text { from storms } G \text { through } L\end{array}$ \\
\hline 2 & 100 \\
3 & 125 \\
4 & 170 \\
6 & 200 \\
8 & 250 \\
AM 3 & 255 \\
AM 20 & 260 \\
AM 21 & 260 \\
AM 22 & 260 \\
AM 23 & 260 \\
AM 24 & 260 \\
\hline
\end{tabular}


Contours of the amount of snow accumulated during storms $\mathrm{G}$ through $\mathrm{L}$, over the time interval of 26 July to 26 August 1961, are shown in Fig. 10. The water equivalent of this snow is tabulated below. It was calculated from a depthdensity profile measured in the new snow on 26 August, together with the depthdensity profile of Pit 5 made on 15 August.

\section{Snow Depth (cm.)}

\section{0}

100

150

200

250

300

\section{Water Equivalent (cm.)}

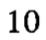

22

40

57

73

92

\section{Annual Accumulation}

Accumulation is greater in the caldera than in the North Crater. This is apparent from the contours in Fig. 10 and from the stratigraphic profiles in Fig. 6. Also, within the North Crater large variations in accumulation occur because of topographic complexities over short distances. Pit 3 near the north rim of the North Crater received more accumulation from storms C, D, E, and F in 1961 than did Pit 2. However, it shows less accumulation than Pit 2 between the 1961 summer and the time when the dirty melt layer formed. From the point of view of determining annual accumulation the dirty layer is especially valuable and we shall attempt to date it.

The dirty melt layer is such an exceptional feature in the snow strata on Mount Wrangell that it is reasonable to expect that the conditions which formed it will be identifiable in the climatological records. The meteorological records at the Gulkana FAA station are the best available long-range records of climate in the immediate vicinity of Mount Wrangell. The summit of the mountain is easily visible from this station which is only $74 \mathrm{~km}$. away from it. Large storms affect both the mountain top and the Gulkana FAA station. Some stormy weather on the mountain top does not affect the lowland, and conversely, sometimes the valleys are overcast by clouds which lie below the mountain tops (see Fig. 11).

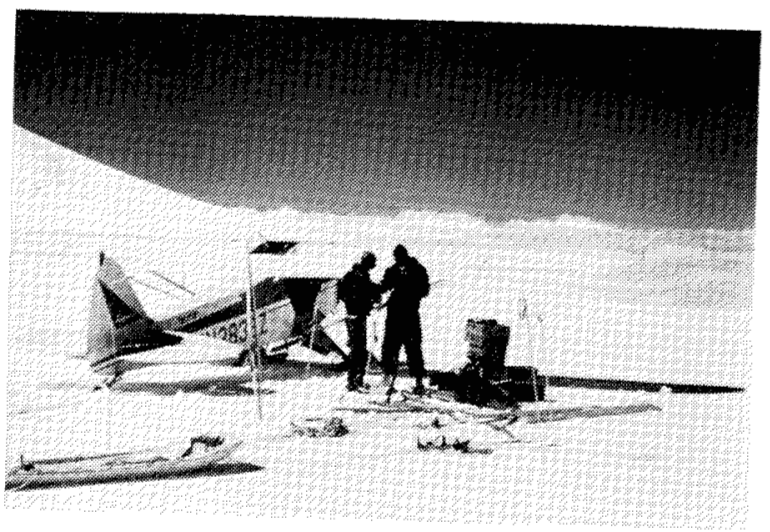

FIG. 11. Ski-wheel Piper Super Cub on top of Mt. Wrangell. A representative freight load of about $135 \mathrm{~kg}$. has just been unloaded onto the snow. Occasionally, clear weather prevailed on the mountain top with a nearly solid cloud cover below, as shown here. 
TABLE 4. Air Temperatures Measured at the Gulkana FAA Station.

\begin{tabular}{ccccc}
\hline \multicolumn{5}{c}{ Number of days with temperature greater than: } \\
Year & $80^{\circ} \mathrm{F}$. & $77^{\circ} \mathrm{F}$. & $70^{\circ} \mathrm{F}$. & $68^{\circ} \mathrm{F}$. \\
\hline 1963 & $26.7^{\circ} \mathrm{C}$. & $25^{\circ} \mathrm{C}$. & $21.1^{\circ} \mathrm{C}$. & $20^{\circ} \mathrm{C}$. \\
1962 & 2 & 7 & 30 & 39 \\
1961 & 8 & 14 & 37 & 46 \\
1960 & 0 & 5 & 20 & 30 \\
1959 & 6 & 9 & 21 & 30 \\
1958 & 3 & 9 & 33 & 42 \\
1957 & 10 & 18 & 33 & 41 \\
1956 & 18 & 35 & 54 & 61 \\
& 4 & 8 & 24 & 40 \\
\hline
\end{tabular}

However, prolonged spells of hot, sunny weather, which affect both the Gulkana FAA Station and the mountain top, are the best times for potential melting of snow on the mountain. An excellent index of this weather is found by considering the days when the temperature at the Gulkana FAA Station exceeds certain values. When the air temperature at the Gulkana air strip exceeds $25^{\circ} \mathrm{C}$. the skies are clear and warm sunny weather prevails on the mountain. The number of days when the Gulkana FAA records show temperatures in excess of selected temperatures is summarized in Table 4.

Table 4 shows that the differences between years increase when higher temperatures are used as the reference base. The years 1958 and 1957 stand out as exceptionally warm; they both had several prolonged periods of dry sunny weather. Accordingly, the melt-rich dirty layer, which is the first layer with abundant melt evidence in all pits, is attributed to the 1958 summer.

In addition to being hot, the 1958 summer was very dry and many forest fires occurred in interior Alaska. Indeed, excellent statistics for comparing summer climates are provided by the "Buildup Index" of the National Fire Danger rating system, U.S. Forest Service. The Buildup Index is based on temperature, humidity, and the cumulative dryness of the basic types of potential forest-fire fuels. The monthly averages of the Buildup Index, summarized in Table 5, clearly show

TABLE 5. Monthly Averages of the Forest Fire "Buildup Index"* in the Gulkana Area.

\begin{tabular}{lrrrrrrrr}
\hline Month & 1956 & 1957 & 1958 & 1959 & 1960 & 1961 & 1962 & 1963 \\
\hline April & 0 & 0 & 1 & 0 & 1 & 0 & 0 & 0 \\
May & 25 & 21 & 30 & 17 & 39 & 30 & 9 & 32 \\
June & 60 & 69 & 101 & 48 & 33 & 38 & 30 & 61 \\
July & 42 & 49 & 75 & 27 & 31 & 51 & 35 & 70 \\
August & 27 & 57 & 27 & 26 & 38 & 34 & 89 & 86 \\
September & 37 & 43 & 51 & 43 & 12 & 21 & 31 & 87 \\
\hline
\end{tabular}

*The Buildup Index of the National Fire Danger Rating System, U.S. Forest Service, is computed by taking into account the air temperature, the humidity, and the cumulative dryness of potential forest fire fuels. Data furnished by Wm. Trigg, Forest Fire Forecast Meteorologist, U.S. Bureau of Land Management, Fairbanks, Alaska. 
TABLE 6. Adjustment of Accumulation Data to 26 August 1961 Reference Level.

\begin{tabular}{ccrcc}
\hline & & \multicolumn{2}{c}{$\begin{array}{c}\text { Accumulation added between date } \\
\text { of Pit Study and 26 August 1961 }\end{array}$} \\
Pit & Date of Pit Study & cm. snow & cm. water equiv. \\
\hline 2 & 19 July 1961 & 125 & 39 \\
3 & 23 July 1961 & 170 & 53 \\
4 & 1 August 1961 & 100 & 27 \\
5 & 15 August 1961 & 80 & 16 \\
\hline
\end{tabular}

the exceptionally hot, dry nature of the 1958 summer. The dryness helps to account for the "dirtiness" of the dirty melt layer, because the reduced snowfall on the mountain could be expected to provide maximum exposure of volcanic ash and dirt deposits for the wind to pick up.

The 1957 summer was also exceptionally hot (Table 4) and could be expected to contribute to the abundant melt evidence several metres below the dirty melt layer. This is additional support for the interpretation which assigns the dirty melt layer to 1958 .

Once we accept the 1958 date for the dirty melt layer it is possible to calculate the accumulation at Pits 2, 3, 4 and 5 for the three years 1958 to 1961 . To have a common origin date, the record at each pit will be adjusted to the date of 26 August 1961. This can be done easily since the amount of snow added between 26 August and the date the pit study was made is known. The adjustments are shown in Table 6.

Since the summer surfaces of 1961 and 1958 are identified in the snow of Mount Wrangell, one cannot resist seeking the 1960 and 1959 summer surfaces which lie between them. This can be done by examining the stratigraphic records from the pit studies. The analysis is based on the same general principles used in polar snow such as on the Greenland Ice Sheet. These principles have been described in detail with many examples by Benson (1962a). In general, winter snow is finer grained, harder, and has higher density than summer snow. If melt evidence exists it will, of course, be in the summer strata. The most convenient reference datum in the annual stratigraphic cycle forms at the end of summer. This is because the fall season produces a unique record in the form of a low density depth hoar layer which is generally overlain by finer grained harder, denser snow than that below. If melt evidence exists it lies below the depth hoar layer. If only one depth hoar layer formed, and only one change from low to high density snow occurred each year, one could call this an "ideal profile". Frequently there is more than one depth hoar layer and it is necessary to become familiar with the annual sequences of strata in any given area.

On Mount Wrangell the stratigraphic interpretation is complicated by two factors:

(1) The large amounts of accumulation, and

(2) The frequent occurrence of rime ice layers.

The accumulation from a single storm on Mount Wrangell often leaves a 
TABLE 7. Annual Units Recognized in Pits 2, 3, 4 and 5, 1961.

\begin{tabular}{|c|c|c|c|c|c|}
\hline Pit & Year & $\begin{array}{l}\text { Depth Below } \\
\text { Snow Surface } \\
\quad(\mathrm{cm} .)\end{array}$ & $\begin{array}{l}\text { Water equivalent, } \\
\text { or load, } \\
\left(\mathrm{cm} . \mathrm{H}_{2} \mathrm{O} \text {, or }\right. \\
\left.\text { g. } \mathrm{cm}^{-2}\right)\end{array}$ & $\begin{array}{c}\text { First yr. accum. } \\
\text { adjusted to } 26 \text { Aug. } \\
1961 \\
\text { (Table 6.) }\end{array}$ & $\begin{array}{l}\text { Water equivalent } \\
\text { of annual unit } \\
\text { (cm. } \mathrm{H}_{2} \mathrm{O} \text {, or } \\
\text { g. } \mathrm{cm} \cdot-2 \text { ) }\end{array}$ \\
\hline 2 & $\left\{\begin{array}{l}1961 \\
1960 \\
1959 \\
1958 \\
1957\end{array}\right.$ & $\begin{array}{r}0 \\
280 \\
440 \\
645 \\
755\end{array}$ & $\begin{array}{r}0 \\
95 \\
168 \\
260 \\
311\end{array}$ & 39 & $\begin{array}{r}134 \\
73 \\
92 \\
51\end{array}$ \\
\hline 3 & $\left\{\begin{array}{l}1961 \\
1960 \\
1959 \\
1958 \\
1957\end{array}\right.$ & $\begin{array}{r}0 \\
230 \\
430 \\
560 \\
680\end{array}$ & $\begin{array}{r}0 \\
80 \\
168 \\
226 \\
280\end{array}$ & 53 & $\begin{array}{r}133 \\
88 \\
58 \\
54\end{array}$ \\
\hline 4 & $\left\{\begin{array}{l}1961 \\
1960 \\
1959 \\
1958 \\
1957\end{array}\right.$ & $\begin{array}{r}0 \\
220 \\
320 \\
410 \\
510\end{array}$ & $\begin{array}{r}0 \\
72 \\
115 \\
154 \\
200\end{array}$ & 27 & $\begin{array}{l}99 \\
43 \\
39 \\
46\end{array}$ \\
\hline 5 & $\left\{\begin{array}{l}1961 \\
1960 \\
1959 \\
1958 \\
1957\end{array}\right.$ & $\begin{array}{r}0 \\
400 \\
620 \\
830 \\
?\end{array}$ & $\begin{array}{r}0 \\
136 \\
233 \\
330 \\
?\end{array}$ & 16 & $\begin{array}{c}152 \\
81 \\
97 \\
?\end{array}$ \\
\hline
\end{tabular}

record which resembles an annual unit on an ice sheet. For example, the first metre at each pit in Fig. 6 could easily pass for annual units on the stratigraphic sheets from Greenland (Benson 1962a).

Rime ice layers form during storms and are not associated with hot sunny weather which produces surface melting. However, the record left by small formation of rime ice can resemble a surface melt crust. Such rime ice layers are predominantly summer features but they spread out the summer record in the strata beyond the limits which would be affected solely by normal surface melt crusts.

The locations of the 1960 and 1959 summers are indicated in Fig. 6. The locations are not unequivocal; and where the summer strata show several layers with melt evidence an attempt has been made to locate the uppermost part of the summer i.e., the onset of fall and winter. The depth to each annual reference datum is listed in Table 7. The water equivalent of the snow lying above the reference datum is listed along with the depth. The water equivalent of the first year has been adjusted to the 26 August 1961 level according to Table 6. Estimates for the location of the 1957 Fall discontinuity are also listed for some pits in Table 7.

The stratigraphic analysis summarized in Table 7 indicates average annual accumulation values over the three-year span from the 1958 summer to 26 August 1961 as follows:

$\begin{array}{cc}\text { Pit } & \text { cm. water equivalent per year } \\ 2 & 100 \\ 3 & 93 \\ 4 & 60 \\ 5 & 110\end{array}$


These average values do not, of course, indicate the variations from year to year; it should be kept in mind that the 1961 accumulation exceeded the average value for the two preceding years by factors of $1.6,1.8,2.4$ and 1.7 at Pits 2,3 , 4 and 5, respectively. The differences from one pit to the next can easily be attributed to topographical effects as discussed above. And, although the variation in accumulation from year to year is significant, it is reasonable to expect at least $100 \mathrm{~cm}$. water equivalent per year in the centre parts of the caldera and adjacent craters at the summit of Mount Wrangell.

\section{FACIES}

Temperature, density, and ram hardness data from the top of Mount Wrangell indicate that its snow cover is close to, but slightly below, the dry snow line. These variables will be discussed individually, but the above summarizing statement is based on a lumped consideration of them, together with stratigraphic observations in the pit walls. The latter, taken individually, would locate the area high in the percolation facies, although Pit 5 could possibly be put in the dry-snow facies.

\section{Temperature}

A Weston bimetallic thermometer (range $-50^{\circ}$ to $+25^{\circ} \mathrm{C}$.) inserted into a block of styrofoam insulation, was lowered to the bottom of core holes to obtain mean annual temperatures. The thermometer was allowed to come to equilibrium with the temperature at the bottom of the core hole by leaving it in place overnight. The thermometer was then pulled up to be read and the insulation kept it from responding to temperature differences during the time required to pull it up the core hole. The following results were obtained:

$\begin{array}{cccc}\text { Pit } & \text { Temp. }{ }^{\circ} \mathrm{C} . & \text { Depth }(\mathrm{cm} .) & \text { Time and Date } 1961 \\ 2 & -19.5 & 975 & 11: 10 \text { Fri. 21 July } \\ & -19.6 & 975 & 16: 00 \text { Sat. 22 July } \\ 3 & -15.5 & 1010 & 17: 07 \text { Tues. 25 July } \\ & -15.7 & 1010 & 20: 55 \text { Tues. 25 July } \\ 4 & -16.0 & 1010 & 10: 50 \text { Thurs. 27 July } \\ 4 & -12.5 & 976 & 18: 15 \text { Sun. 6 August } \\ & -12.5 & 976 & 10: 24 \text { Mon. 7 August } \\ 5 & -19.0 & 1100 & 10: 30 \text { Wed. 16 August }\end{array}$

The data clearly show the effect of volcanic heating. Pits 3 and 4 , close to the rim of the North Crater, have temperatures $3.5^{\circ} \mathrm{C}$. and $7.0^{\circ} \mathrm{C}$. higher respectively than Pit 2 in the centre of this crater. Pit 5 in the caldera is farthest from exposed rock, and its temperature of $-19^{\circ} \mathrm{C}$. compares well with the $-19.5^{\circ} \mathrm{C}$. at Pit 2; indeed, part of this difference may be attributed to the $115 \mathrm{~m}$. difference in altitude between the two points. The $10 \mathrm{~m}$. temperatures measured at Pits 2 and 5 will be accepted as the best available data, and a mean annual temperature of $-20^{\circ} \mathrm{C}$. is assumed for the $4,200 \mathrm{~m}$. altitude on Mount Wrangell.

On interior parts of the Greenland Ice Sheet, where the amplitude of average monthly temperatures deviates $20^{\circ} \mathrm{C}$. from the mean annual value, the dry-snow line is located at places where the mean annual temperature is $-25^{\circ} \mathrm{C}$. Mount 
Wrangell is strongly influenced by a maritime climate, therefore its temperature amplitude may be expected to be less than that of interior Greenland. Thus, the mean annual temperature of $-20^{\circ} \mathrm{C}$. places the summit area of Mount Wrangell very near the dry-snow line.

\section{Density}

The average density for the top $5 \mathrm{~m}$. of snow, and the load $5 \mathrm{~m}$. below snow surface on Mt. Wrangell are as follows:

$\begin{array}{ccc} & \begin{array}{c}\text { Average density of } \\ \text { top } 5 \mathrm{~m} .\left(\mathrm{gm} . / \mathrm{cm}^{3}\right)\end{array} & \begin{array}{c}\text { Load } 5 \mathrm{~m} . \text { below snow } \\ \text { surface }\left(\mathrm{gm} . / \mathrm{cm}^{2}{ }^{2}\right)\end{array} \\ 5 & 0.360 & 180 \\ 3 & 0.398 & 199 \\ 2 & 0.390 & 195 \\ 4 & 0.390 & 195\end{array}$

According to these data Pit 5 is in the dry-snow facies, Pits 2 and 4 lie on the dry-snow line, and Pit 3 is in the upper part of the percolation facies just below the dry-snow line (Benson 1962a, pp. 71-73).

\section{Ram Hardness}

Integrated ram hardness profiles (Benson 1962a, pp. 61-67) measured on Mount Wrangell are as follows:

\begin{tabular}{ccccl}
\multicolumn{3}{c}{ Integrated Rammsonde } & Profiles (joules) \\
Pit & $\mathbf{R}_{1}$ & $\mathbf{R}_{2}$ & $\mathbf{R}_{3}$ & $\mathbf{R}_{4}$ \\
5 & 141 & 531 & 1208 & 2671 \\
3 & 175 & 896 & 1610 & 3171 \\
2 & 96 & 428 & 2010 & 5751 \\
4 & 85 & 448 & 1803 & 3194
\end{tabular}

These values indicate that Pit 2 lies in the upper percolation facies whereas the others nearly straddle the dry-snow line (Benson 1962a, pp. 65-66).

\section{METEOROLOGY}

Meteorological data from the top of Mount Wrangell are limited to:

(1) hourly temperatures, obtained from thermograph data, 4-21 July, 1954 (Fig. 12),

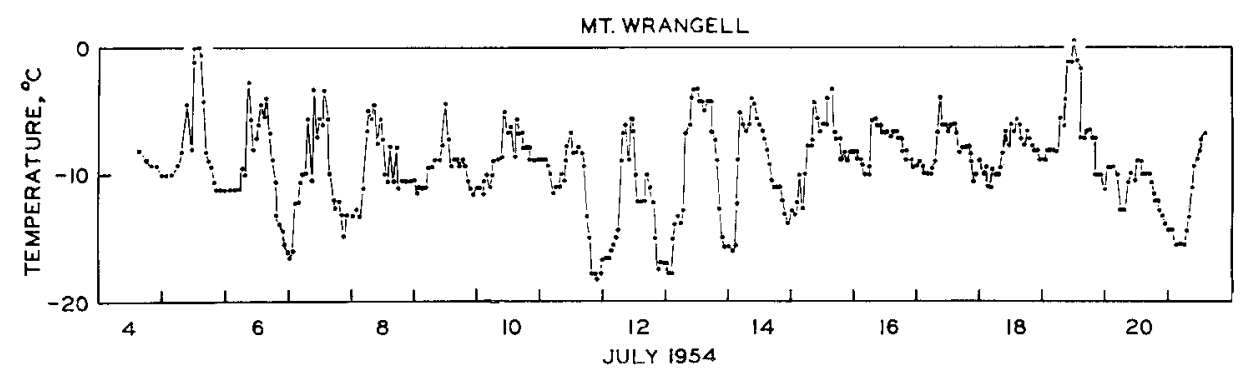

FIG. 12. Air temperature data on Mt. Wrangell, 4-21 July 1954. The hourly values plotted here were taken from a thermograph record obtained on the ridge near W2 by F. A. Milan and R. W. Elsner of the U.S. Air Force Arctic Aeromedical Laboratory, Ladd AFB, Alaska. 


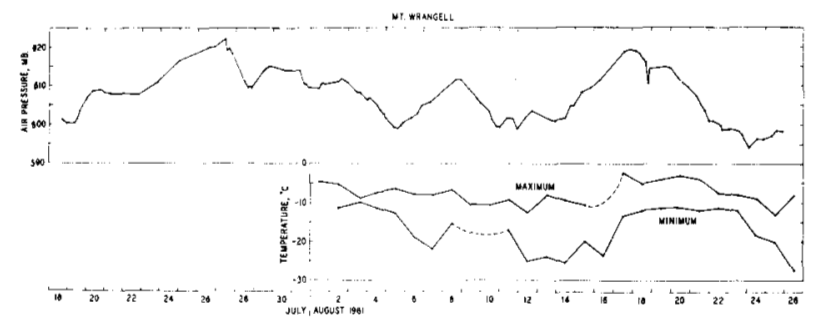

FIG. 13. Air pressure and maximum-minimum air temperature for parts of July and August 1961. Air pressure was measured by a Paulin System altimeter.

(2) air pressure data, obtained with a Paulin System altimeter, 18 July-26 August 1961 (Fig. 13), and

(3) maximum-minimum air temperature data, 1-26 August 1961 (Fig. 13). (In 1961 the shelter for max.-min. thermometers was not available on the mountain until 1 August. It filled with snow on several occasions, which caused blank spots in the record.)

The July and August temperatures ranged from $0^{\circ} \mathrm{C}$. (on 12 and $19 \mathrm{July}$ 1954) to $-26^{\circ}$ C. on 26 August 1961. The pressure in July and August of 1961 ranged from 594 to $622 \mathrm{mb}$. The only anemometer on the mountain in 1961 failed to operate after becoming jammed during an attempt to measure gusty winds which contained abundant blowing snow. However, snowfall was invariably associated with wind from the south as summarized in Table 1.

The interpretation of abnormally heavy accumulation on Mount Wrangell during 1961 is supported by an analysis of the meteorological records from Paxson $\left(63^{\circ} 03^{\prime} \mathrm{N}\right.$.; $145^{\circ} 30^{\prime} \mathrm{W}$; $823 \mathrm{~m}$.) done by Mayo (1963) in connection with his study on the Gulkana Glacier $\left(63^{\circ} 13^{\prime} \mathrm{N}\right.$.; $145^{\circ} 27^{\prime} \mathrm{W}$.) in the Alaska Range. A 7-year mean (discontinuous observations 1914 to 1944 , station reopened in 1960) indicates that 1961 precipitation was 1.7 times greater than the average. At $2,300 \mathrm{~m}$. altitude on the Gulkana glacier the 1961 accumulation was 1.7 times greater than that measured during 1959-1961 (Mayo 1963). (The exact agreement between these values is coincidental [Mayo, personal communication]). During the abortive effort to work on Mount Wrangell in 1962, much less snow was on the rim of the North Crater than had been observed in 1961. In particular, the patch of bare ground near W2 was much larger in 1962 (Figs. 2 and 14).

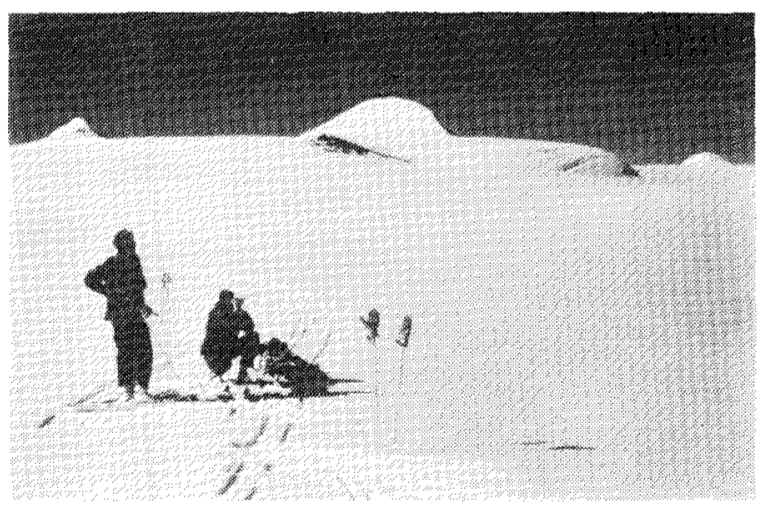

FIG. 14. View towards the North Crater from point AM-1 in the caldera. The left hand peak is W6, the right hand one is W7. Point W2 is to the right of the hut which may be seen on top of the exposed patch of bare ground near centre in the photo. Since 1962, the amount of exposed bare ground has increased to nearly four times the area exposed in this photo which was taken on 26 July 1961 , during placement of the AM series of poles. All transport of equipment was done by manhauling sledges as shown. 


\section{VOLCANIC HEAT}

\section{Temperature Gradients in the Sand and Ash}

Specimens of exposed volcanics, including ash, lapilli, scoria and flow rocks were collected from the summit area. These most recent lavas and pyroclastics from Mt. Wrangell are hypersthene-augite andesites, typical of Pacific rim andesites (Benson and Forbes, 1965). All observed outcrops had temperatures above $0^{\circ} \mathrm{C}$. at the surface and exceeded $+25^{\circ} \mathrm{C} .1 \mathrm{~m}$. below the surface. Active hydrothermal alteration may be observed in several localities. The most prominent one is near W3 (Fig. 15). Here the surface is covered with red clay which contains many small fumaroles. The highest measured temperatures were obtained in this locality; they were as follows:

$+32^{\circ} \mathrm{C}$, $3 \mathrm{~cm}$. below surface, $5 \mathrm{~m}$. down slope from W3, 7 August 1961.

$+95^{\circ} \mathrm{C}$., $12 \mathrm{~cm}$. below surface, $10 \mathrm{~m}$. down slope from W3, 7 August 1961. Both of these temperatures exceeded the upper range $\left(+25^{\circ} \mathrm{C}\right.$.) of the thermometer, and were estimated by observing the needle as it went around its scale the second time. The value, $95^{\circ} \mathrm{C}$., is assumed to be erroneously high because the boiling point of water in the pressure range 594 to $622 \mathrm{mb}$. (Fig. 13) is $85.6^{\circ}$ to $86.8^{\circ} \mathrm{C}$. Water rapidly evaporated from the slopes of W3 and W2 and sponsored large clouds from the active crater after every new snowfall.

Seven temperature gradients were measured in the ash-sand layers near W2 and W2A. The 6 gradients measured near W2 were nearly linear at $0.3^{\circ} \mathrm{C} . \mathrm{cm} . .^{-1}$ in the depth range observed $(0$ to $120 \mathrm{~cm}$.). The range of temperatures increased, approximately $0.6^{\circ} \mathrm{C} . \mathrm{m} .^{-1}$, as the point of measurement was moved downward along the snow-free part of the inner caldera wall at W2. The gradient at W2A was the lowest $\left(0.2^{\circ} \mathrm{C} . \mathrm{cm} .{ }^{-1}\right)$ observed. It was measured in small (approx. $5 \mathrm{~m} .{ }^{2}$ ) exposure of bare sand and ash, surrounded by snow cover.

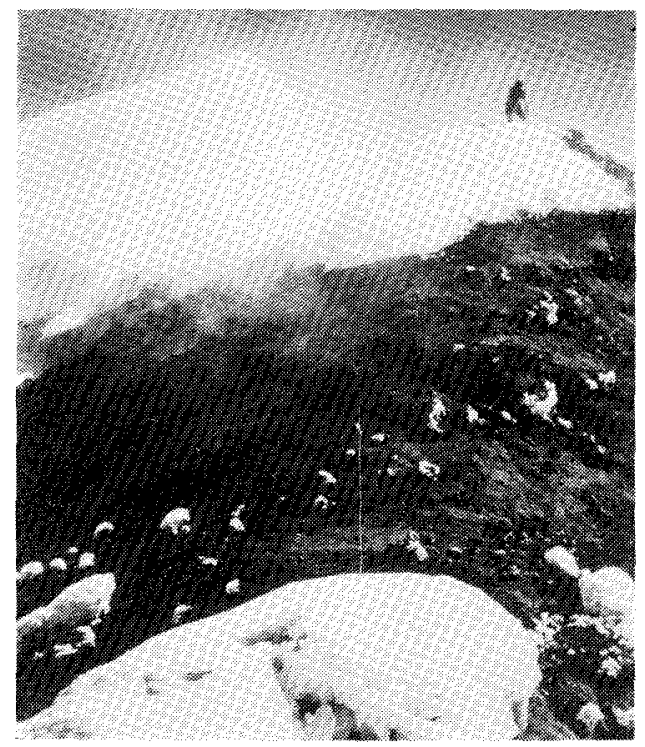

FIG. 15. Triangulation point W3. Aside from the active crater, the W3 area is the most active. This cone is covered by red clay which is a hydrothermal alteration product of the andesitic rocks of the summit area. The air temperature was about $-10^{\circ} \mathrm{C}$. when this photo was taken, while the temperature $10 \mathrm{~cm}$. below the clay surface was near the boiling point of water $\left(86^{\circ} \mathrm{C}\right.$.). The vapour comes from many small fumaroles which are about $1 \mathrm{~cm}$. diameter and spaced about $1 \mathrm{~m}$. apart. 


\section{Temperature Gradients in the Snow, I Horizontal}

The effect of volcanic heat on the snow cover of Mount Wrangell produced "horizontal" temperature gradients in the snow on the order of 0.01 to $0.04{ }^{\circ} \mathrm{C}$. m. ${ }^{-1}$. "Horizontal" refers to the depth $10 \mathrm{~m}$. below snow surface, and the gradients were calculated by using the following values for $10 \mathrm{~m}$. temperatures:

$\left.\begin{array}{cr}\text { Pit } & 10 \mathrm{~m} . \text { temperature }{ }^{\circ} \mathrm{C} . \\ 5 & -19.0 \\ 3 & -16.0 \\ 2 & -19.5 \\ 4 & -12.5\end{array}\right\}$ to the nearest $1 / 2{ }^{\circ} \mathrm{C}$.

In the North Crater the distances between pit sites and the differences in $10 \mathrm{~m}$. temperatures produce the following temperature gradients:

$\begin{array}{lccc} & \text { Distance } m . & \Delta T^{\circ} C . & \frac{\Delta T}{\Delta X}{ }^{\circ} C \cdot m \cdot .^{-1} \\ \text { Pit } 2 \text { to Pit 3 } & 280 & 3.5 & 0.012 \\ \text { Pit 2 to Pit 4 } & 160 & 7.0 & 0.044 \\ \text { Pit } 3 \text { to Pit } 4 & 350 & 3.5 & 0.010\end{array}$

In the caldera it is safe to assume that all rock-ice contacts are at $0^{\circ} \mathrm{C}$. On the basis of estimated distances from Pit 5 to points on the rim near surveyed points, we obtain:

$\begin{array}{lccc} & \begin{array}{c}\text { Estimated } \\ \text { Distance } m .\end{array} & \Delta T^{\circ} C . & \frac{\Delta T}{\Delta X}{ }^{\circ} C \cdot m \cdot \cdot^{-1} \\ \text { Pit } 5 \text { to W3 } & 2000 & 19 & 0.010 \\ \text { Pit } 5 \text { to W4 } & 1500 & 19 & 0.013 \\ \text { Pit } 5 \text { to W5A } & 1500 & 19 & 0.013\end{array}$

\section{Temperature Gradients in the Snow, II Vertical}

A vertical temperature gradient in the snow and ice cover on Mount Wrangell can be estimated by making some assumptions. First, we shall assume the snow and ice in the North Crater to be $300 \mathrm{~m}$. thick. This is a reasonable assumption based on comparison of the North Crater with the active crater on the new U.S.G.S. 1:63, 360 map. The mean annual temperature at the volcanically heated ice-rock interface is at the pressure melting point which is essentially $0^{\circ} \mathrm{C}$. If a linear temperature gradient is assumed it turns out to be $0.07^{\circ} \mathrm{C} . \mathrm{m}^{-1}$ which is slightly greater than, but of the same order of magnitude as, the horizontal gradients of 0.01 to $0.04^{\circ} \mathrm{C} . \mathrm{m}^{-1}$ described above.

\section{Heat Flow and Its Effect on Mount Wrangell Glaciers}

Heat flow at the exposed bare ground surface may be estimated if we assume a value of thermal conductivity, $\mathrm{k}$, for the damp ash-sandy material. Reasonable values are 0.003 to $0.006 \mathrm{cal} . \mathrm{cm}^{-1}{ }^{\circ} \mathrm{C}^{-1} \mathrm{sec}^{-1}$ (Ingersoll et al. 1948; Kersten 1952). Using these values, together with the temperature gradients of $0.3^{\circ} \mathrm{C} . \mathrm{cm} .^{-1}$ measured in the sand and ash, we obtain heat flow values of $9 \times 10^{-4}$ to $18 \times 10^{-4}$ cal. $\mathrm{cm} .^{-2} \mathrm{sec}^{-1}$. This rate of heat flow would be sufficient to melt 350 to $700 \mathrm{~cm}$. 
of ice per year. These values were estimated for places where bare ground is exposed and where the volcanic heat flow is obviously more than adequate to melt the annual increment of accumulation. Indeed, in this case the "ablation" by volcanic heat exceeds the annual accumulation by factors of 3.5 to 7 .

The heat flow is not uniform over the summit area of Mount Wrangell. The existence of the active crater and several concentrations of fumaroles around the rim of the caldera is ample evidence of this. Similarly, the persistent bare ground areas are warmer than average for the summit area. Thus, the above heat flow values cannot be applied to the entire rock-ice surface of Mount Wrangell.

It is also clear that not all of the volcanic heat is available to melt ice, for two reasons:

1) Some heat is conducted through the snow and ice because of the existing temperature gradients, and

2) Some heat is required to raise the temperature of the snow to the melting point.

The amount of heat flow involved in both of these processes is about $0.35 \times 10^{-4}$ cal. $\mathrm{cm}^{-2} \mathrm{sec}^{-1}$. This is an order of magnitude less than the amount of heat flow required to melt the amount of snow added annually at the summit of Mount Wrangell. In terms of equivalent quantities of ice melted, it would be adequate to melt about $13 \mathrm{~cm}$. of ice per year, $12 \mathrm{~cm}$. of which are due to the latter process alone. The calculations which yielded these values are outlined as follows:

1) The heat flow across the temperature gradient in the snow and ice was based on the assumption that the depth-density profile on top of Mount Wrangell is comparable to that near the dry-snow line in Greenland (Benson 1962a; Anderson and Benson 1963). Values for thermal conductivity (k), and specific heat (c) were averaged from the Smithsonian Meteorological Tables, (1963) and from Goldstein (1951). The specific values used are as follows:

\begin{tabular}{|c|c|c|c|}
\hline $\begin{array}{l}\text { Depth interval } \\
\text { (m.) }\end{array}$ & $\begin{array}{l}\text { Density } \\
\text { gm. cm. }\end{array}$ & Cal. cm..$^{-1}{ }^{\circ} \mathrm{C}^{-1} \mathrm{sec}^{-1}$ & Cal. gm.-1 ${ }^{\circ} \mathrm{C}^{-1}$ \\
\hline $0-100$ & 0.72 & 0.003 & 0.5 \\
\hline $100-300$ & 0.90 & 0.005 & 0.5 \\
\hline
\end{tabular}

Using these values the heat flow across the vertical temperature gradient of $0.07^{\circ} \mathrm{C}$. m. ${ }^{-1}$ calculated above, is $0.03 \mathrm{cal} . \mathrm{cm}^{-2} \mathrm{sec}^{-1}$ which is adequate to melt about $1 \mathrm{~cm}$. of ice per year.

2) The amount of heat used to warm the snow from its mean annual temperature of $-20^{\circ} \mathrm{C}$. at the snow surface to $0^{\circ} \mathrm{C}$. at the rock-ice interface may be estimated by assuming a steady-state system. Thus, the amount of material added each year at the upper surface at $-20^{\circ} \mathrm{C}$. will be compensated by an equal amount delivered at $0^{\circ} \mathrm{C}$. to the lower surface. The annual accumulation is taken to be $100 \mathrm{~cm}$. of water (or ice) equivalent and the amount of heat required to raise the temperature of this from $-20^{\circ} \mathrm{C}$. to $0^{\circ} \mathrm{C}$. in one year is equal to a heat flow of $.32 \times 10^{-4} \mathrm{cal} . \mathrm{cm}^{-2} \mathrm{sec}^{-1}$ which, in turn, is adequate to melt $12 \mathrm{~cm}$. of ice per year.

The heat flow calculated for bare ground areas is the right order of magnitude, but 3 to 7 times more than adequate, to melt the amount of ice added annually. 
The heat flow averaged over the entire summit area is clearly less than this since glaciers do exist and flow outward in all directions from Mount Wrangell. However, large amounts of snow and ice are melted by volcanic heat, and the effects of this may show up in the nature of glacier flow in the area, and in the volume, and physical-chemical properties of the water flowing in streams from the Wrangell Range. One of these effects may be the large-scale distribution of snow and ice in the Wrangells. Mount Wrangell lies near the western end of the Wrangell Range, whereas the longest glaciers are in the eastern part; this could well be a gross effect of the heat sources centred at Mount Wrangell.

\section{SURFACE MOTION}

A 3-dimensional Cartesian coordinate system was set up with origin at point W2 (Fig. 2). The positive $\mathrm{X}$ axis points true east and goes directly through point W3. The positive $Y$ axis is true north. The altitude of W2 was determined to be $4160 \mathrm{~m}$. by triangulation to point W9 the highest point on Mount Wrangell. Thus, the coordinates of $W 2$ are $(0,0,4160)$. The motion of AccumulationMovement (AM) markers in the snow was computed from angles measured, with a Wild T-2 Theodolite, at the fixed points W1, W2, and W3. The University of Alaska's IBM 1620 computer was used for the calculations.

Motion measurements were made on stakes AM-1 to AM-19. Good motion data were obtained from 9 of these 19 stakes as summarized in Table 8 and plotted in Fig. 2. The 1961 surveying program was beset with difficulties, mostly due to weather, some of which are outlined below. The entire 1961 surveying effort was carefully reviewed by Douglas $K$. Bingham in connection with the extension of the work in 1965. Corrections for errors in some measurements, together with the reasons for eliminating stakes 8,10 and 12 through 19 are discussed in detail by Bingham (1967).

The flow velocities were calculated from the best two sets of measurements. The first set took two days to complete, readings were made from W3 on 29 July and from W2 on 1 August. The second set was made from both W2 and W3 on 15 August. The time interval between the two sets of readings was taken to be 15.5 days.

TABLE 8. Surface Velocities.

\begin{tabular}{rccc} 
Stake & $\begin{array}{c}\text { Distance Moved } \\
(\mathrm{cm} .)\end{array}$ & $\begin{array}{c}\text { Velocity } \\
\left(\mathrm{cm} . \text { day }^{-1}\right)\end{array}$ \\
\hline AM & 1 & 16 & 1.03 \\
2 & 36 & 2.32 \\
3 & 53 & 2.42 \\
4 & 76 & 4.91 \\
5 & 74 & 4.78 \\
6 & 83 & 5.36 \\
7 & 91 & 5.87 \\
9 & 70 & 4.52 \\
11 & 58 & 3.74 \\
\hline
\end{tabular}




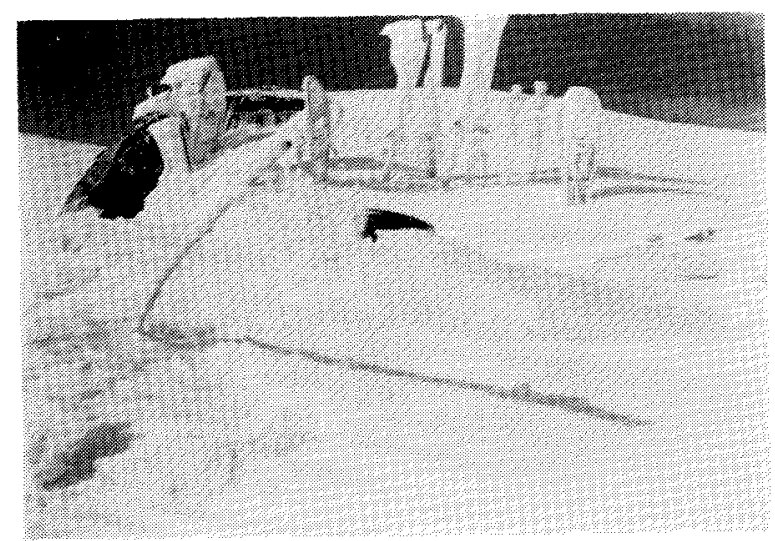

FIG. 16. Heavy rime ice accumulation on the morning of 23 August 1961. Abundant rime ice formed during storms $\mathrm{E}, \mathrm{H}$, and $L$ as described in Table 1. It was difficult to maintain meteorological instruments at these times.

As previously pointed out, it was not possible to set out the entire AM marker network on one day. Also because of stormy weather it was rarely possible to occupy and take measurements from both ends of a single base line on the same day. Measurements at one end of a base line were sometimes interrupted by 2 or more days of weather with such low visibility and high winds that surveying was impossible. During such time intervals the stakes in the snow continued moving, so it was necessary to begin the survey over again at the first opportunity.

Another source of error was the formation of rime ice on the bamboo poles which caused them to bend (Fig. 16). The amount of such error may be illustrated by an extreme hypothetical example. If a pole leans $15^{\circ}$ from the vertical while $2 \mathrm{~m}$. of snow are deposited around it, there would be an apparent displacement of $53.5 \mathrm{~cm}$. To minimize these errors angles were measured to individual poles by sighting at the bottom, i.e., where the pole met the snow surface. Rime ice formed discontinuously and was cleaned from the poles at every opportunity. Most of the poles AM-1 to AM-19 were fairly well buried before occurrence of the worst rime-forming conditions on 18-19 and 22-23 August, during storm $L$. The extreme conditions shown in Fig. 15 formed during the night of 22-23 August. Poles AM-20 to AM-30 were more severely affected by this storm since they were installed later and protruded farther from the snow surface; no useful motion data were obtained from these poles. Rime formed on the south (windward) side and rime-laden poles generally leaned south because of this. Several poles with thick rime deposits were lost either by breakage, or by being buried as they leaned during deposition of new snow.

Some of the motion data suggested that volcanic heat influences the flow of ice near the active crater and near W3. However, it has not been possible to sort out real effects from errors. Because observations were restricted to a short and interrupted time interval and complicated by rime ice formation it is best not to attempt detailed explanations of the surface velocity data. The observations have raised questions which hopefully will lead to additional and more refined observations. At present it may be stated that the surface flow velocity in the caldera centre is about $5 \mathrm{~cm}$. day ${ }^{-1}$ or nearly $20 \mathrm{~m} . \mathrm{yr}^{-1}$. 


\section{ACKNOWLEDGEMENTS}

This reconnaissance study was jointly supported by the Cold Regions Research and Engineering Laboratory (CRREL), Hanover, N.H. under Contract DA-11-190ENG-131, and by a Grant from Dr. Terris Moore, former president of the University of Alaska. The continued interest and encouragement from Dr. Moore are greatly appreciated. Colonel W. L. Nungesser, Director, and Mr. James A. Bender, Chief of the Research Branch of CRREL, made arrangements for field equipment and rations to be provided from Fort Wainwright and Fort Greely and authorized the participation of two army men in the work. Valuable assistance in the field was provided by R. C. King, J. W. Leach and S. W. Scott. Special thanks are due to D. K. Bingham for his careful analysis of the 1961 motion study program and to Jack Wilson of Wilson Flying Service for fitting our demands into his heavily committed schedule.

\section{REFERENCES}

ANDERSON, D. L. and C. S. Benson. 1963. The Densification and Diagenesis of Snow, in Ice and Snow, Properties, Processes and Applications, Edited by W. D. Kingery. Cambridge, Mass.: M.I.T. Press, pp. 391-411.

BEISER, A. 1953. Mt. Wrangell Expedition. Physics Today, October 1953, pp. 10-14.

BENSON, C. S. 1962a. Stratigraphic Studies in the Snow and Firn of the Greenland Ice Sheet, SIPRE Research Report 70,93 pp.

1962b. Distribution of Mean Annual Temperature on the Greenland Ice Sheet. Bulletin of the American Meteorological Society, 43: 139.

1963. Reconnaissance Snow Studies on Mt. Wrangell, Alaska. Geophysical Institute, University of Alaska, Final Report prepared for CRREL under Contract No. DA 11-190-ENG-131, 38 pp.

1967. Polar Regions Snow Cover, in: Physics of Snow and Ice, Proceedings of the Sapporo Conference 1962, Part 2. Sapporo, Japan: The Institute of Low Temperature Science, Hokkaido University. pp. 1039-1063.

BENSON, C. S. and R. B. FORBES. 1965. Reconnaissance Glaciological and Volcanological Studies, Mt. Wrangell, Alaska (abstract), Proceedings of the 15th Alaskan Science Conference, pp. 93-94.

BINGHAM, D. K. 1967. Ice Motion and Heat Flow Studies, Mt. Wrangell, Alaska, Unpublished M.S. Thesis, University of Alaska, $117 \mathrm{pp}$.

GIOvinetTo, M. 1960. USNC-IGY Antarctic Glaciological Data, Field Work 1958 and 1959 (South Pole Station), Report 825-2 - Part IV, Ohio State University Research Foundation.

Goldstein, R. J. 1951. Thermal Properties, in Review of the Properties of Snow and Ice, SIPRE Report 4, Edited by H. T. Mantis, Chapter V.

INGersoll, L. R., o. J. zOBEL, and A. C. INGERSOLl. 1948. Heat Conduction. New York: McGraw-Hill Book Co. Inc.

Kersten, M. s. 1952. Thermal Properties of Soils, in Frost Action in Soils - A Symposium, Highway Research Board, Special Report No. 2, pp. 161-166, National Academy of Sciences - National Research Council publication No. 213.

MAYO, L. 1963. 1961 Meteorology and Mass Balance of Gulkana Glacier, Central Alaska Range, Alaska, Unpublished M.S. Thesis, University of Alaska.

MOCK, s. J., and w. F. WeEks. 1966. The Distribution of 10 meter Snow Temperatures on the Greenland Ice Sheet, Journal of Glaciology, 6: 23-41.

RUTTER, N. W. 1961. Foliation and other Structures of Gulkana Glacier, Alaska, Unpublished M.S. Thesis, University of Alaska. $51 \mathrm{pp}$. 
Sellmann, P. v. 1962. Flow and Ablation of Gulkana Glacier, Alaska, Unpublished M.S. Thesis, University of Alaska. $36 \mathrm{pp}$.

SHARP, R. P. 1956. Glaciers in the Arctic, Arctic, 9: 78-117.

SMithsonian Meteorological tables. 1963. (6th Ed.), Prepared by R. J. List. Smithsonian Miscellaneous Collections, Volume 114, Publication 4014, Washington, D.C.

woon, w. A. 1963. The Icefield Ranges Research Project. The Geographic Review, 53: 16384. 